\title{
Extragastric gastrin
}

\author{
M. G. KORMAN, C. SOVENY, AND J. HANSKY \\ From Monash University Department of Medicine, Prince Henry's Hospital, Melbourne, Australia
}

SUMMARY Gastrin release in the basal state and following a standard protein meal has been estimated in patients after partial gastrectomy, partial gastrectomy with truncal vagotomy, and total gastrectomy.

Following partial gastrectomy, gastrin rose from $8 \pm 0.8$ to $20 \pm 3.8 \mathrm{pg} / \mathrm{ml}$ with a protein meal. The rise in the partial gastrectomy with truncal vagotomy group was $27 \pm 0.8$ to $92 \pm 1.5 \mathrm{pg} / \mathrm{ml}$ and after total gastrectomy was $13 \pm 1.5$ to $58 \pm 4.6 \mathrm{pg} / \mathrm{ml}$.

These results provide evidence for the release of gastrin from extragastric sites.

Basal gastrin and the gastrin response to a protein meal are significantly greater after truncal vagotomy for duodenal ulcer than in unoperated patients. It was suggested that part of the gastrin is released as a result of section of extragastric vagal fibres (Korman, Hansky, and Scott, 1972). This has been confirmed by a study of gastrin release following selective gastric vagotomy where significantly lower levels are found (Korman, Hansky, Coupland, and Cumberland, 1972).

The origin of the gastrin released following truncal vagotomy is uncertain but a significant release from extragastric sites has been suggested (Korman et al, 1972). Study of the pattern of gastrin release after partial gastrectomy, partial gastrectomy with truncal vagotomy, and total gastrectomy has enabled examination of this hypothesis.

\section{Material and Methods}

Three groups of patients were studied.

PARTIAL GASTRECTOMY ALONE

Six patients, two females and four males, had a partial gastrectomy of the Polya type, and surgery entailed complete removal of the gastric antrum. Mean age was 48 years (range 37 to 59 years) and surgery was performed for duodenal ulcer from six months to one year previously.

Please address requests for reprints to: M. G. Korman, Monash University Department of Medicine, Prince Henry's Hospital, Melbourne, Victoria 3004, Australia.

Received for publication 11 January 1972.
PARTIAL GASTRECTOMY AND TRUNCAL VAGOTOMY

Six patients, two females and four males, had a Polya gastrectomy combined with truncal vagotomy. Mean age was 52 years (range 42 to 64 years) and surgery was performed for duodenal ulcer from six months to three years previously. Completeness of vagotomy had been confirmed by the finding of no acid secretory response to insulin hypoglycaemia (Hollander, 1946).

\section{TOTAL GASTRECTOMY}

Three male patients comprised the group. Indication for surgery was gastric carcinoma in two patients and recurrent oesophageal stricture in the other. Ages were 48, 54, and 64 years, and surgery had been performed from one to four years previously. Total gastric excision had entailed complete truncal vagotomy.

All patients investigated were free of significant gastrointestinal symptoms at the time of study. Following an overnight fast, each patient had a peripheral vein cannulated and blood collected for gastrin determination $\mathbf{3 0}$ minutes before, at the time of, and at 15-minute intervals for two hours after a standard protein meal (Korman, Soveny, and Hansky, 1971). The cannula was kept patent by frequent flushing with a solution of 1000 units of heparin in $20 \mathrm{ml}$ of $0.9 \%$ saline.

Serum gastrin was estimated by radioimmunoassay (Hansky and Cain, 1969; Hansky, Soveny, and Korman, 1971).

Statistical analysis of group means was performed 
by Student's $t$ test using standard formulae (Snedecor and Cochran, 1968).

\section{Results}

The serum gastrin response to a protein stimulus for each group is shown in the figure.

\section{PARTIAL GASTRECTOMY}

Mean \pm SEM basal gastrin was $8 \pm 0.8 \mathrm{pg} / \mathrm{ml}$ which rose significantly to a peak of $20 \pm 3.8 \mathrm{pg} / \mathrm{ml}$ at 60 minutes after protein $(P<0.025)$.

\section{PARTIAL GASTRECTOMY WITH TRUNCAL} VAGOTOMY

Mean basal gastrin was $27 \pm 0.8 \mathrm{pg} / \mathrm{ml}$ which rose significantly to a peak of $92 \pm 1.5 \mathrm{pg} / \mathrm{ml}$ at 90 minutes after protein $(P<0.0005)$.

\section{TOTAL GASTRECTOMY}

Mean basal gastrin was $13 \pm 1.5 \mathrm{pg} / \mathrm{ml}$ which rose significantly to a peak of $58 \pm 4.6 \mathrm{pg} / \mathrm{ml}$ at 75 minutes after protein $(\mathrm{P}<0.0025)$.

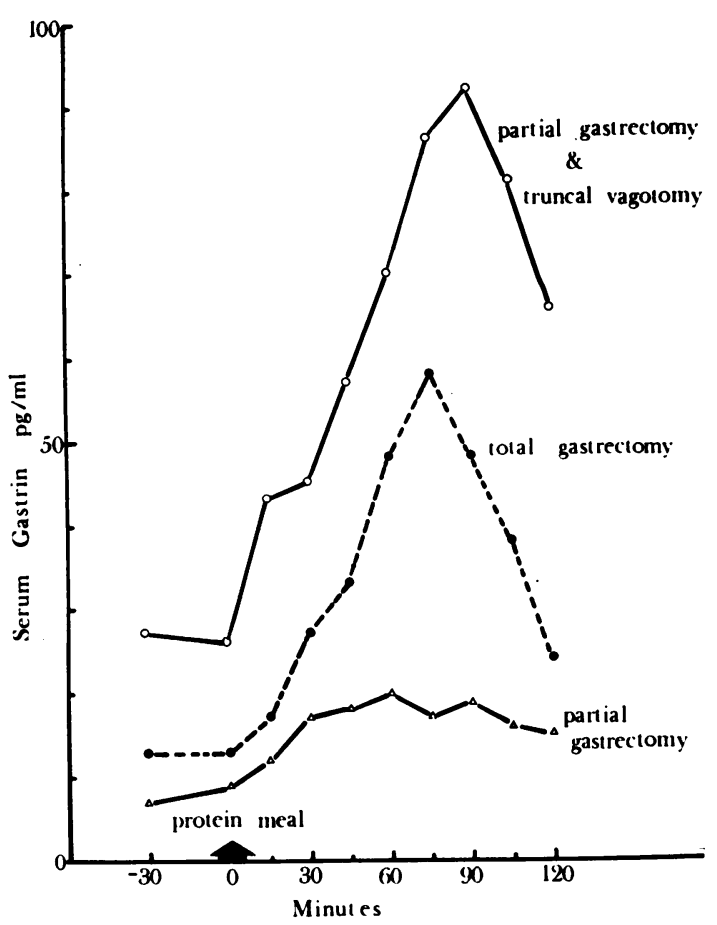

Fig. The figure shows the mean serum gastrin response to a standard protein meal in patients who have undergone partial gastrectomy alone (six patients), partial gastrectomy and truncal vagotomy (six patients), and total gastrectomy (three patients).
COMPARISON OF BASAL LEVELS

The difference between the mean basal gastrin of patients with partial gastrectomy and those with total gastrectomy was not significant. Mean basal gastrin of patients with partial gastrectomy and truncal vagotomy was significantly higher than with partial gastrectomy alone $(\mathrm{P}<0.0005)$ or total gastrectomy $(P<0.0005)$.

COMPARISON OF RESPONSE TO A PROTEIN MEAL The peak rise in serum gastrin of patients with partial gastrectomy and truncal vagotomy was significantly greater than with either partial gastrectomy alone $(\mathrm{P}<$ $0.0005)$ or total gastrectomy $(P<0.0025)$. The peak rise in the total gastrectomy group was significantly greater than those with partial gastrectomy alone $(P<0.0005)$.

\section{Discussion}

The present study has offered firm evidence that additional gastrin is released following section of extragastric vagal fibres. This is shown by the significantly higher rise of serum gastrin in patients who had undergone partial gastrectomy and truncal vagotomy compared with patients who had undergone partial gastrectomy alone. That the gastrin is released from extragastric sites is confirmed by the significant response observed in patients who have had a total gastrectomy which, in each case, involved truncal vagotomy.

Protein meal stimulation indicates that a small amount of gastrin is released from the body of the stomach. This is illustrated by the patients who had partial gastrectomy alone and increased their serum gastrin by $12 \mathrm{pg} / \mathrm{ml}$. McGuigan (1968) has shown the presence of a small number of gastrin-secreting cells in the body of the normal stomach by immunofluorescence. Stimulation of these cells may produce the small amount of gastrin detected in the antrectomized patient. The patients with partial gastrectomy and truncal vagotomy raised their serum gastrin by $64 \mathrm{pg} / \mathrm{ml}$ and the total gastrectomy group by 46 $\mathrm{pg} / \mathrm{ml}$. Allowing at least $12 \mathrm{pg} / \mathrm{ml}$ to come from the gastric remnant, the responses in these two groups are very similar.

Thus a significant percentage of the gastrin released following truncal vagotomy is derived from extragastric sites. Korman et al (1972) speculated that the origin of this gastrin was most likely the duodenum. Berson and Yalow (1971) have demonstrated the presence of immunoreactive gastrin in the duodenum and jejunum of man, and Emås, Borg, and Fyrö (1971) have also shown the presence of gastrin in human duodenum by bioassay. 
Middleton, Kelly, Nyhus, and Harkins (1965) demonstrated that dogs with denervated pouches, total gastrectomy, and truncal vagotomy increased pouch secretion of acid significantly in response to food as compared with the situation when the extragastric fibres were intact. They suggested that extragastric vagotomy may produce the release of intestinal gastrin. Clearly they showed the release of a gastric acid stimulant and the present results show that this stimulant is gastrin. Another site for gastrin release may be the pancreas. The presence of gastrin cells in human pancreatic islets has been demonstrated by immunofluorescence (Lomský, Langr, and Vortel, 1969; Greider and McGuigan, 1971). The present study has not identified the extragastric site of gastrin release after total gastrectomy. The answer may well come from studies following vagotomy, antrectomy, and either enterectomy or pancreatectomy in the experimental animal.

We thank Professer J. McK. Watts, Mr P. Hunt, and R. Marshall for allowing us to study their patients. This work was supported by grants from the National Health and Medical Research Council of Australia.

\section{References}

Berson, S. A., and Yalow, R. S. (1971). Nature of immunoreactive gastrin extracted from tissue of gastrointestinal tract. Gastroenterology, 60, 215-222.

Emås, S., Borg, I., and Fyrö, B. (1971). Antral and duodenal gastrin activity in non-ulcer and ulcer patients. Scand.J. Gastroent., 6, 39-43.

Greider, M. H., and McGuigan, J. E. (1971). Cellular localization of gastrin in the human pancreas. Diabetes, 20, 389-396.

Hansky, J., and Cain, M. D. (1969). Radioimmunoassay of gastrin in human serum. Lancet, 2, 1388-1390.

Hansky, J., Soveny, C., and Korman, M. G. (1971). Effect of secretin on serum gastrin as measured by immunoassay. Gastroenterology, 61, 62-68.

Hollander, F. (1946). The insulin test for the presence of intact nerve fibers after vagal operations for peptic ulcer. Gastroenterology, 7, 607-614.

Korman, M. G., Hansky, J., and Scott, P. R. (1972). Serum gastrin in duodenal ulcer. III. Influence of vagotomy and pylorectomy. Gut, 13, 39-42.

Korman, M. G., Soveny, C., and Hansky, J. (1971). Effect of food on serum gastrin evaluated by radioimmunoassay. Gut, 12, 619-624.

Korman, M. G., Hansky, J., Coupland, G. A. E., and Cumberland, V. H. (1972). Serum gastrin in duodenal ulcer. IV. Effect of selective gastric vagotomy. Gut, 13, 163-165.

Lomský, R., Langr, F., and Vortel, V. (1969). Immunochemical demonstration of gastrin in mammalian islets of Langerhans. Nature (Lond.), 223, 618-619.

McGuigan, J. E. (1968). Gastric mucosal intracellular localization of gastrin by immunofluorescence. Gastroenterology, 55, 315-327.

Middleton, M. D., Kelly, K. A., Nyhus, L. M., and Harkins, H. N. (1965). Selective vagal effects on the intestinal phase of gastric secretion. Gut, 6, 296-3c0.

Snedecor, G. W., and Cochran, W. G. (1968). Statistical Methods, 6th ed., pp. 91-119. Iowa State University Press, Ames, Iowa. 